\title{
FOUR YEAR RESULTS OF CONSERVATIVE TREATMENT OF BENIGN STRICTURES OF THE ESOPHAGUS WITH SAVARY GILLIARD TECHNIQUE OF BOUGIENAGE: CROSS-SECTIONAL STUDY REPRESENTING FIRST EXPERIENCES IN REPUBLIC OF MACEDONIA
}

\author{
Vladimir Andreevski, Gorgi Deriban, Urim Isahi, Jane Mishevski, Magdalena Dimitrova, \\ Viktorija Caloska, Nenad Joksimovic, Rozalinda Popova, Vladimir Serafimovski \\ University Clinic of Gastroenterohepatology, Medical Faculty, University "Ss. Cyril and Methodius" Skopje, Republic of \\ Macedonia
}

Corresponding author: Vladimir Andreevski, University Clinic of Gastroenterohepatology, Medical Faculty, University "Ss. Cyril and Methodius" Skopje, Republic of Macedonia, email: banebumbar_med@hotmail.com

\section{ABSTRACT}

Background: Benign esophageal strictures are complications resulting from various causes. They can be structurally categorized in two groups: simple and complex. Treatment is similar in most cases that require dilatation and means use of three general types of dilators that are currently in use. However, despite the last guidelines on esophageal dilatation, the therapeutic response, optimal timing of treatment and interval between sessions may vary and there is no strong consensus in the literature regarding this fact.

Aims: To analyzethe first 4 year experience of Digestive Endoscopy Unit at the University Clinic of Gastroenterohepatology of the Medical Faculty, Skopje, Republic of Macedonia in treating benign esophageal strictures, since the Savary-Gilliard technique of "bougienage" was introduced for the first time in Republic of Macedonia, at our Institution, in December 2013, by assessing etiology, length of stricture, number of dilations required to achieve satisfactory therapeutic response, as well as the relationship between the type, extent of stenosis and therapeutic response.

Methods: One hundred and forty five dilations, during a period from 20th December 2013, until March 2017, have been analyzed in 31 patients

Results: The caustic strictures were the most prevalent, occurring in $15(48 \%)$ of patients, followed by peptic stenosis presenting $26 \%$ of patients. The long and corrosive strictures needed more sessions to the absence of dysphagia. Peptic and short stenoses best respondedon treatment and needed fewer dilatation sessions per patient.

Conclusion: Caustic stricture is the most common type of benign esophageal stenosis and the most refractory to treatment, especially the long one. Peptic stenosis is the second cause of benign esophageal strictures and responded well to endoscopic therapy. The higher the extent of stenosis, the greater the number of sessions required. Short strictures have good prognoses in most cases. The number of dilations depended directly on the cause and extent of stenosis. Bouginage using Savary-Gilliard or American type of technique, irrespective of the type and the extent of esophageal stenosis, is safe and purposeful procedure.

Keywords: Esophageal stenosis, bouginage.

\section{INTRODUCTION}

Benign esophageal strictures are complications that result from various causes, such asgastroesophageal reflux disease, accidental or deliberate ingestion of corrosive substances, congen- ital rings and esophageal membranes, radiation therapy, eosinophilic esophagitis etc. They can be structurally categorized into two groups: simple and complex. [1] Simple strictures are symmet- 
ric or concentric, usually short with a diameter of $12 \mathrm{~mm}$ or more andeasily allow passage of a diagnostic upper endoscope. Complex strictures have one or more of the following features: asymmetry, diameter $<12 \mathrm{~mm}$ or inability to pass an endoscope. Regardless of the cause, dysphagia as symptom is a main indication for dilation of benign strictures. [2] Treatment is similar in most cases that require dilatation and means use of three general types of dilators that are currently in use. These are: (1) mercury or tungsten-filled bougies (Maloney or Hurst), (2) wire-guided polyvinyl dilators (Savary-Gilliard or American type), and (3) "through-the-scope" balloon dilators. The technic using Maloney/Hurst or Savary-Gilliard dilators is known well as 'bougienage'. The degree of dilation within a session should be based on the severity of the stricture. The "rule of 3" has been accepted and applied to bougie dilation of esophageal strictures. [3] Specifically, the chosen initial dilator should be based on the estimated stricture diameter. Serial increases in diameter are then performed. However, despite the last ASGE guideline on esophageal dilatation from 2006 [4], the therapeutic response, optimal timing of treatment and interval between dilatation sessions can vary and there is no strong consensus in the literature regarding this fact.

Dilatation of esophageal strictures in Republic of Macedonia and at the University Clinic of Gastroenterohepatology is not new. The use of olive dilators was introduced at our Clinic few decades ago. The University Clinic of otorhinolaryngology has long experience using mercury or tungsten-filled bougies (Maloney/Hurst),as well as the Clinic of Pediatric Surgery. In this retrospective study, we present the first 4 year experience of Digestive Endoscopy Unit of the University Clinic of Gastroenterohepatology atthe Medical Faculty, Skopje, Republic of Macedonia, in treating benign esophageal strictures, since the Savary-Gilliard technique of "bougienage" was introduced for the first time in Republic of Macedonia, at our Institution, in December 2013.

\section{METHODS}

All dilations, independently of their type and origin, were analyzed, during a period from December $20^{\text {th }}, 2013$, until March 2017. The dilations performed out with technic of bouginage were excluded.
The dilations were performed in an in-hospital setting, with one to two week intervals between sessions. All of the interventions were conducted by three experienced endoscopysts covering the whole number of 31 patients (19, 8 and 4 patients per operator, respectively). The procedure was performed with the patient fasting for at least 12 hours, under conscious sedation using midazolam and continuous pulse-oximetry and post procedural temperature and blood pressure monitoring. Although routine antibiotic coverage is not recommended mandatory before the procedure, [4] we used ceftriaxone $2 \mathrm{~g}$ i.v. for prophylaxes of septic events. We used a flexible metal guide wire, introduced through the stricture under endoscopic vision and X-ray control, wherein passing the Savary-Gilliard type bougies [Safe Guide TM, Over the Guidewire Esophageal Dilators with 16 sizes: 15 FR to 60 FR - in 3 FR increments - equivalent values in $\mathrm{mm}$ - from 5 to $20 \mathrm{~mm}$ (Medovations inc., 102 East Keefe Avenue, Milwaukee, wi53212 USA].

The initial diameter of the candle is individualized according to the degree of stenosis displayed.

Data were collected according to the cause, type and extent of stenosis. According to the type, the strictures were classified as simple and complex. The extent was used to classify them as short - up to $3 \mathrm{~cm}$, medium - between 3 and 7 $\mathrm{cm}$, and long - more than $7 \mathrm{~cm}$ in length. These variables were correlated with the number of dilations. The influence of etiology in the extent of stenosis was also analyzed. The ultimate goal of treatment was absence or marked reduction of dysphagia.

\section{Statistical analysis}

For statistical analysis of data Pearson contingency coefficient test was used (by analyzing the influence of sex on the extent of stenosis) and ANOVA (analysis of variance of the influence of the extent and etiology on the number of dilations). The level of significance was expressed as $\mathrm{P}<0.05$.

\section{RESULTS}

One hundred and eighty three dilations were analyzed during a period from 20-th December 2013, until March 2017, conducted in 66 
patients. Thirty eight dilations were excluded, concerning the 25 cases of patients where balloon dilation technic was used. In other words, 145 dilations, performed by using technic of bouginage in 31 patients (13 women and 18 men with a mean age of 52.4 years, ranging from $1-82$ years), during a period of more than 4 years, were analyzed.

The caustic stricture was the most prevalent, occurring in 15 (48\%) patients, followed by peptic stenosis presenting $8(26 \%)$ patients.

Table 1. Causes of benign esophageal strictures in 31 patients

\begin{tabular}{lcc}
\hline Cause & Number & $\%$ \\
Caustic & 15 & 48 \\
Peptic & 8 & 26 \\
Postoperative & 3 & 10 \\
Membranes and rings & 1 & 3 \\
Post irradiation & 4 & 13 \\
Total & 31 & 100 \\
\hline
\end{tabular}

Regarding the extent of stenosis, all individuals were evaluated of the total 31 included, and it was observed that $61 \%(19 / 31)$ had short nips, representing the majority of peptic stenosis. Long length stenoses were exclusively present in patients whose origin was caustic. The recurrence rate in the last, despite the high number of sessions needed to provide positive effect, was low. Forty six $\%$ of 31 patients were free from symptoms following the finish of therapy.

Table 2. Length of stenosis

\begin{tabular}{lcc}
\hline Extent of stenosis & Number & $\%$ \\
Short & 19 & 61 \\
Medium & 3 & 10 \\
Long & 9 & 29 \\
Total & 31 & 100 \\
\hline
\end{tabular}

Peptic was predominantly short stenosis - in 8 of 31 patients analyzed for extent (26\%). The opposite occurred in the caustic stenosis that have predominantly long changes ( 8 of 15 patients with corrosive injury analyzed for extent - 53.3\%). Stenoses, due to esophageal surgery, were also short ( 3 of 3 patients - 100\%).

Caustic injuries were those that needed more sessions, on average 6.6 dilations per patient (maximum 21 sessions in one patient), a statistically significant difference in relation to other causes $(\mathrm{P}<0.0005)$. However, analyzing separately the postoperative cases, peptic and all other types between each other, there was no sig- nificant difference between the average number of dilations $(\mathrm{P}=0.175667)$.

Table 3. Relation among cause of benign esophageal strictures and number of dilations

\begin{tabular}{lc} 
Cause & Number of bouginage per patient \\
Caustic & $6.6^{*}$ \\
Peptic & $2.3^{* *}$ \\
Postoperative & $2.2^{* *}$ \\
Membranes and rings & $2.2^{* *}$ \\
Post irradiation & $3.1^{* *}$ \\
$\quad$ *ANOVA $-\mathrm{P}<0.005$ & \\
$\quad *$ ANOVA $-\mathrm{P}=0.175667$ & \\
\hline
\end{tabular}

Nips long segment strictures required on average 7.9 interventions per patient, while narrowing short extension stenosis required about 2.8 dilations per patient $(\mathrm{P}<0.00001)$.

The most treated patient was the one from the caustic group, who underwent 21 dilations.

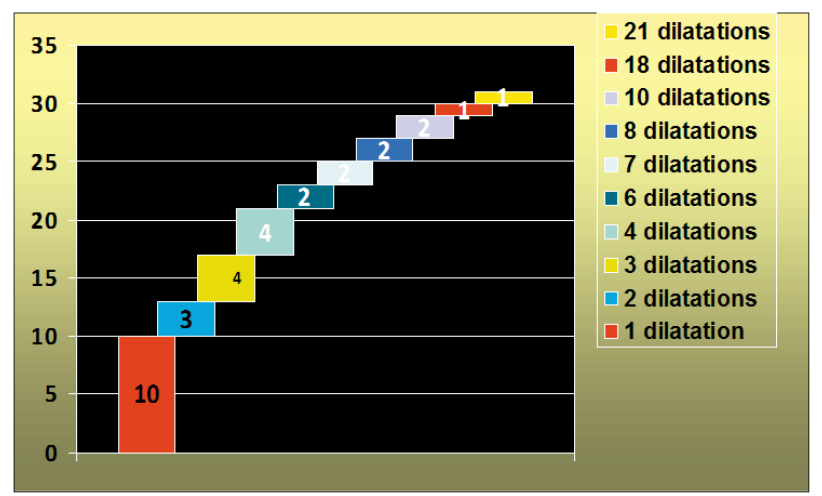

Diagram 1. Number of dilations per each patient treated

In 145 dilations performed, there were no perforations. There was minor bleeding in all patients, but not more than usual and no mortality was registered in this seria.

\section{DISCUSSION}

The causal diagnosis of stenosis may be established at $80 \%$ of cases, using only the anamnesis. A barium swallow does much to define the degree of stenosis, location, determine the complexity and choose the type of dilator to be used, and usually is used as the initial examination. Upper endoscopy is essential, because it evaluates the mucosa of the affected region, excluding malignant causes and enables the performance of biopsies to be done even when the etiologic diagnosis is evident. 
Corrosive agents when ingested accidentally (in children mostly) or intentionally (adults in suicide attempts) can cause esophageal strictures, which bring the higher risk of perforation and more expressed rate of recurrence after dilation compared to other types. [5, 6] Endoscopic examination in the acute phase may indicate the prognosis. Tiryaki et al. [7] observed a better therapeutic response when dilation was initiated in the acute phase, seven days after the ingestion of corrosive agent. In this study, we started bouginage in caustic cases at least 1 month after the accident, and the success rate was pretty high - $44 \%$ without additional need for treatment, and most of the others who need additional treatment with de novo symptoms 6 months after the initial session. The affected segment extension is also a prognostic factor. In this series, we observe that themore extensive the stenosis was; the greater was the needed number of dilations . After the disappearance of symptoms, the need for retreatment was usually within 3-6 months in the first year. Temir et al. [8] defends the opinion that implementation of new dilations should only be done when reappearance of dysphagia is registered.

An estimated $7 \%$ to $23 \%$ of patients with longstanding gastroesophageal reflux disease (GERD) evolve with esophageal stenosis. [9] As shown in this study, they are generally annular stenosis (shorter than $<3 \mathrm{~cm}$ ), typically located on the distal segment of the esophagus. This type of stenosis responds very well to dilation therapy, with successful rate greater than $80 \%$. [5] The therapy with proton pump inhibitors (PPIs) in full dose and anti-reflux measures should always be carried out.

Patients undergoing esophageal surgery, especially esophagectomies and even hernia repair surgeries, may develop stenosis, either due to developing local ischemia, use of "stapler" technic or by the scar processing. The success rate of endoscopic dilations in these patients is around $75 \%$ to $92 \%$, usually requiring about three to five sessions for resolution of symptoms. [13] In this sample, it was found that three patients with postoperative stenosis required on average 3 sessions for good response. According to our opinion, it is safe and recommended to start the expansion immediately after appearance of dysphagia, which is opposite to other experts recommendations, taking cut of value of 2 weeks after surgery as relevant one. In addition, the ideal period hasnt't been determined yet. [13]
It is known that only after 24 hours of use of a nasogastric tube, intraepithelial and submucosal edema and hemorrhage of the esophagus appear and if the probe remains in situ for more than 5 days, hyperemia as well as presence of ulcerations can be detected. This occurs either by direct local irritation by the probe, as well as a result of facilitation of gastroesophageal reflux. There was no patient in this series diagnised with stenosis resulting from the use of nasogastric tube.

Radiotherapy may cause stenosis by direct damage to DNA and producing free radicals which stimulate cell death. The incidence is around $25 \%$ to $67 \%$ in the irradiated patient to primary tumor and from $1 \%$ to $20 \%$ for irradiation of tumors arising from adjacent organs (breast, lung, thyroid). [13] In this study, the post-radiotherapy stenosis was uncommon, occurring in only 4 patients (13\%) who required averagely 3 dilation sessions to achieve therapeutic response.

Eosinophilic esophagitis, predominant entity in children, in which there is chronic inflammation of the esophagus, characterized by infiltration of more than 20-24 eosinophils per high-power field, detected by histopathology, is still underdiagnosed cause in adults with esophageal stenosis. The treatment includes endoscopic dilation, removal of the triggering factor (usually airborne allergens and food allergens) and topical steroids. In the present study we assessed only one patient with this diagnosis, requiring one expansion sessions adjacent to topical steroid therapy, for dysphagia remission.

Esophagitis caused by ingestion of drugs in pill form results from infrequent stenosis. Medications such as tetracycline, nonsteroidal antiinflammatory drugs, potassium chloride and bondronates can cause stenosis by direct injury to the mucosa due to prolonged contact, decreased motor activity and decreased esophageal clearance. This study can't confirm the use of drugs to cause stenosis.

Membranes and rings are causes of stenoses that respond very well to endoscopic dilatation. In the case of Schatzki's rings, $68 \%$ of patients remain without dysphagia for a period of 1 year after the first expansion, but many need new dilations throughout their life. [10] In the present study, evaluated patients with Schatzki ring show good response to endoscopic treatment.

Length of stricture best correlates with its cause, and it was found that according to the causes, strictures have their own behavior. Thus, caus- 
tic strictures are generally long, opposite to peptic strictures that are short.

When comparing the number of dilations undertaken with the cause and extent of the stenosis, it has been found that short lesions or annular, such as peptic and postoperative can be treated by the smaller number of dilations. Already caustic stenoses, usually long, required quite a large number of sessions. The decision on the type of dilator to be used depends on the availability of the material and the experience of each service and it's endoscopysts. In our service where this study was conducted, we used Savary-Gilliard dilatators, consisting of flexible polyvinyl material, and progressed through the stenosis, guided by the passage of a guide wire. The use of fluoroscopy during the procedure, which has been released in the last period in most other services, can be useful in cases of tortuous and complex strictures and provides greater security to the procedure, allowing full control of the dilator and guidewire positioning and minimizing the risk of perforation. Thus, the complication rate is lower, we suppose.

There is no consensus on the follow-up of these patients. Moura et al. [11] suggests that the expansion should be weekly at 1 month, biweekly in 2 of 21 in 21 days in 3 and 4 months and monthly in 5,6 and 7 months. The patient would then be instructed to return if still recounting the symptoms or if there was return of dysphagia, being considered the case as refractory if these complaints occurred in less than 3 months after the last expansion. Some authors [12] recommended that the patient must be kept in the expansion program at short intervals (weekly or biweekly) at the start of therapy until the ultimate goal is reached, the absence of dysphagia; others [13], however, argue the progression to higher candle (45Fr or more), even if the patient is already asymptomatic. [14] In our study, in most cases, the patients were kept under one to two weekly dlation program until the absence of dysphagia. Most of the patients didn't need to reach the maximum size of dilators $(60 \mathrm{Fr}$ $-20 \mathrm{~mm}$ ) for absence of symptoms.

Immediate and postponed complications after dilation occur in $0.5 \%$ to $1.2 \%[2,21]$ and excess bleeding may occur in less than $0.5 \%$ of the cases [15] and bacteremia $20 \%-45 \%$. In this study, there were no cases of perforation and bacteriemia, proving that the procedure is very safe.

The use of corticosteroid (triamcinolone) at the site of stenosis or intralesional (in tears after expansion) is used in some centers because it is believed that by inhibiting, the synthesis of collagencan reduce the number of sessions. $[16,17$, 18] No patient in this study underwent intralesional corticosteroid injections.

\section{CONCLUSION}

In this study, caustic stricture is the most common type of benign esophageal stenosis and the most refractory to treatment, especially the long stretch. Peptic stenosis is the second cause of benign esophageal strictures and responded well to endoscopic therapy in accordance with the literature. The higher the extent of stenosis, the greater the number of sessions required. Short strictures have good prognoses in most cases. The number of dilations depended directly on the cause and extent of stenosis. Bouginage, irrespective of the type and extent of esophageal stenosis, is safe and grateful procedure, especially in the setting of lack of referent thoracic surgery for this type of medical condition in Republic of Macedonia.

\section{REFERENCES}

1. Hernandez LV, Jacobson JW, Harris MS. Comparison among the perfo- ration rates of Maloney, balloon, and savary dilation of esophageal strictures. Gastrointest Endosc 2000; 51: 460-2.

2. Lew RJ, Kochman ML. A review of endoscopic methods of esophageal dilation. J Clin Gastroenterol 2002; 35: 117-26.

3. Langdon DF. The rule of three in esophageal dilation. Gastrointest Endosc 1997; 45: 111.

4. ASGE 2006 Guideline by the American Society for Gastrointestinal Endoscopy 0016-5107/32.00 doi: 10.1016/j.gie.2006.02.031.755 Gastrointestinal Endoscopy Volume 63, No.6: 2006.

5. Deviere J. Dilation procedures. In: Tytgat GNJ, Classen M, Waye JD, Nakazawa S, editors. Practice of therapeutic endoscopy. 2nd ed. London: WB Saunders; 2000. p. 29-37.

6. Piotet E, Escher A, Monnier P. Esophageal and pharyngeal strictures: report on 1,862 endoscopic dilatations using the Savary-Gilliard technique. Eur Arch Otorhinolaryngol. 2008; 265: 357-64.

7. Tiryaki T, Livanelioglu Z, Atayurt H. Early bougienage for relief of stricture formation follow- 
ing caustic esophageal burns. Pediatr Surg Int. 2005; 21: 78-80.

8. Temir GZ, Karkiner A, Karaça I, Ortaç R, Ozdamar A. The effectiveness of sucralfate against stricture formation in experimental corrosive esophageal burns. Surg Today. 2005; 35: 617-22.

9. Angel C, Wrenn E, Lobe T. Brain abcess: an unusual complication of multiple esophageal dilatations. Pediatr Surg Int. 1991; 6: 42-3.

10. Deviere J. Dilation procedures. In: Tytgat GNJ, Classen M, Waye JD, Nakazawa S, editors. Practice of therapeutic endoscopy. 2nd ed. London: WB Saunders; 2000. p. 29-37.

11. Moura EG, Maluf F, Chaves D. Esofagite de refluxo e estenose péptica. In Sakai P, Ishioka S, Filho FM, editores. Tratado de endoscopia digestiva diagnóstica e terapêutica. São Paulo: Atheneu; 1999. p. 65-71.

12. Pereira-lima JC, Ramires RP, Zamin I Jr, Cassal AP, Marroni CA, Mattos AA. Endoscopic dilatation of benign esophageal strictures: report on 1043 procedures. Am J Gastroenterol. 1999; 94: 1497-501.

13. Saeed ZA, Winchester CB, Ferro PS, Michaletz PA, Schwartz JT, Graham DY. Prospective ran- domized comparison of polyvinyl bougies and through-the-scope balloons for dilation of peptic strictures of the esophagus. Gastrointest Endosc. 1995; 41: 189-95.

14. Zahid AS, Winchester C, Ferro P, Michaletz P, Schwartz J, Graham D. Prospective randomized comparison of polyvinyl bougies and throughthe-scope balloons for dilation of peptic strictures of the esophagus. Gastrointest Endosc. 1995; 41: 189-95.

15. Nostrant TT, Nandi OS. Esophageal dilatation. Gastroenterologist. 1998; 6: 5-15.

16. Kochhar R, Ray JD, Sriram PV, Kumar S, Singh $\mathrm{K}$. Intralesional streoids augment the effects of endoscopic dilatation in corrosive esophageal strictures. Gastrointest Endosc. 1999; 49: 509-13.

17. Kochhar R, Makharia GK. Usefulness of intralesional triamcinolone in treatment of benign esophageal strictures. Gastrointestinal endosc. 2002; 56: 829-34.

18. Moura EG, Ferrari S, Maluf F. Injeção de antiinflamatório esteróide. In: Sakai P, Ishioka S, Filho FM, editores. Tratado de endoscopia digestiva diagnóstica e terapêutica. São Paulo: Atheneu; 1999. p.3 3-8. 


\title{
Резиме
}

\section{РЕЗУЛТАТИ ОД ЧЕТИРИ ГОДИНИ КОНЗЕРВАТИВЕН ТРЕТМАН НА БЕНИГНИ СТРИКТУРИ НА ХРАНОПРОВОДОТ СО ТЕХНИКАТА НА SAVARY-GILLIARD - „БУЖИРАЊЕ“: СТУДИЈА НА ПРЕСЕК СО ПРЕТСТАВУВАЊЕ НА ПРВИТЕ ИСКУСТВА ВО РЕПУБЛИКА МАКЕДОНИЈА}

\author{
Владимир Андреевски, Ѓорѓ Дерибан, Урим Исахи, Јане Мишевски, Магдалена Димитрова, \\ Викторија Чаловска, Ненад Јоксимовиќ, Розалинда Попова, Владимир Серафимоски
}

Универзитетска клиника за гастроентерохепатологија, Медицински факултет, Универзитет „Св. Кирил и Методиј“, Скопје, Република Македонија

Вовед: Бенигните езофагеални стриктури се јавуваат како компликации од различни причини. Од аспект на структурата, тие можат да се категоризираат во две групи: едноставни и сложени. Третманот е сличен и во поголемиот дел од случаите каде што е потребна дилатација, тоа генерално подразбира примена на три типа дилататори што се моментално во употреба. Сепак, и покрај последните водичи за езофагеалната дилатација, терапевтскиот одговор, оптималното време до отпочнувањето на третманот и интервалот меѓу поединечните сесии, може да се разликува и да варира, и не постои прецизен консензус во литературата во врска со овој факт.

Цел: Да се согледа првичното четиригодишно искуство во лекувањето на бенигните езофагеални стриктури по воведувањето на техниката на Savary-Gilliard - „бужирање“,, за првпат во Република Македонија во декември 2013 година на Одделот за дигестивна ендоскопија на Универзитетската клиника за гастроентерохепатологија на Медицинскиот факултет, Скопје, Република Македонија, анализирајќи ги, притоа, етиологијата, должината на стриктурите и бројот на потребните дилатации за да се постигне задоволителен терапевтски одговор, како и односот меѓу видот, степенот на стеноза и терапевтскиот одговор.

Методи: Кај 31 пациент беа анализирани сто четириесет и пет дилатации во периодот од 20 декември 2013 година до март 2017 година.

Резултати: Каустичните стриктури беа најзастапени и регистрирани кај 15 (48\%) од пациентите, по кои следуваат пептичните стенози, регистрирани кај $26 \%$ од пациентите. За долгите и корозивни стрииктури беа потребни повеќе сесии до постигнување на отсуство на дисфагија. Кусите и пептични стенози покажаа најдобар одговор на третманот и за нив се потребни помалку сесии на дилатација сметано по глава на пациент.

Заклучок: Каустичните стриктури се најчест тип бенигни езофагеални стенози и тие се најотпорни на третман, особено оние што се класифицирани како долги. Пептичните стенози се вториот најчест тип и причина за појава на бенигни езофагеални стриктури и тие добро одговораат на ендоскопските форми на терапија. Колку е повисок степенот на стеноза толку е поголем и бројот на сесии што се потребни за да се постигне терапевтски одговор. Кусите стриктури имаат добра прогноза во повеќето случаи. Бројот на дилатации директно зависи од причината за појава и степенот на стеноза. Техниката на бужирање Savary-Gilliard, или т.н. американски тип на техника, без оглед на видот и степенот на бенигните езофагеални стенози, е безбедна и благодарна техника.

Клучни зборови: езофагеални стенози, бужирање. 